\title{
GENETIC EVALUATION OF SEEDS \\ OF HIGHLY ENDANGERED PINUS ULIGINOSA NEUMANN FROM WEGGINIEC RESERVE FOR EX-SITU CONSERVATION PROGRAM
}

\author{
ANDRZEJ LEWANDOWSKI ${ }^{1}$, JAROSŁAW BURCZYK ${ }^{2}$, \\ WITOLD WACHOWIAK ${ }^{1}$, ADAM BORATYŃSKI ${ }^{1}$, WIESŁAW PRUS-GŁOWACKI ${ }^{3}$ \\ ${ }^{1}$ Institute of Dendrology, Polish Academy of Sciences \\ Parkowa 5, 62-035 Kórnik, Poland \\ e-mail: alew@rose.man.poznan.pl \\ 2 Bydgoszcz University, Department of Genetics \\ Chodkiewicza 30, 85-064 Bydgoszcz, Poland \\ ${ }^{3}$ Adam Mickiewicz University \\ Międzychodzka 5, 60-371 Poznań, Poland
}

(Received: November 2, 2004. Accepted: February 2, 2005)

\begin{abstract}
Peat-bog pine Pinus uliginosa Neumann has become extinct or rare in many parts of Europe. We have investigated the levels of genetic variation and inbreeding in seeds collected from a highly endangered reserve of this species in Poland, using allozymes as genetic markers. Generally, a high level of genetic variation was observed. The mean expected heterozygosity was 0.376 , while average $(\mathrm{Na})$ and effective $(\mathrm{Ne})$ numbers of alleles per locus were 2.45 and 1.67, respectively. Nevertheless, we have detected relatively low levels of outcrossing, and potential biparental inbreeding. The population-wide multilocus outcrossing rate was estimated to be $0.706( \pm 0.091)$, while the minimum variance mean of single-locus estimates was distinctly lower $\left(t_{s}=0.611\right)$. The estimates of outcrossing calculated for individual trees ranged widely from 0.051 to 1.017 , indicating the complexity of outcrossing patterns. The investigated population of $P$. uliginasa from Węgliniec is small and surrounded by extensive forest stands of $P$. sylvestris. Our three-year records of phenological observations demonstrated that flowering periods for $P$. uliginosa and $P$. sylvestris overlap, allowing for cross-pollination. The possibility of $P$. uliginosa pollination by $P$. sylvestris creates a potential danger of genetic erosion of the $P$. uliginosa gene pool. Nonetheless, based on a species specific $c p$ DNA marker we have found that among 533 seedlings of $P$. uliginosa there were only six seedlings carrying $c p$ DNA marker specific for $P$. sylvestris, indicating that such hybridization seems to be rare.
\end{abstract}

KEY WORDS: peat-bog pine, conservation, genetic variation, mating system, hybridization.

\section{INTRODUCTION}

Peat-bog pine Pinus uliginosa Neumann is one of the four native pines in Poland. It reaches there the northern boundary of its natural range, and usually forms small isolated populations on peat lands in the southern part of the country (Boratyński 1994). Morphologically P. uliginosa is considered as an intermediate species between $P$. mugo and $P$. sylvestris (Staszkiewicz 1985) and/or between $P$. mugo and $P$. uncinata (Staszkiewicz and Tyszkiewicz 1972; Krzakowa et al. 1984; Christensen 1987). However, some other studies postulate that $P$. uliginosa is more closely related to $P$. mugo than to $P$. sylvestris (Prus-Głowacki et al. 1998; Lewandowski et al. 2002; Boratyńska et al. 2003). The species has been recently regarded as a stabili- zed hybrid taxon resulting from an ancient cross pollination of the pairs of species mentioned above (Christensen 1987; Lauranson-Broyer et al. 1997; Lewandowski et al. 2000).

One of the best-known locations of peat-bog pine in Poland is the reserve in Wegliniec in the area of Lower Silesian Pinewood (South-Western part of Poland). Nowadays $P$. uliginosa occurs at two sites in the area of the Silesian Pinewood. The four other sites of this taxon known from German literature of the $19^{\text {th }} / 20^{\text {th }}$ centuries have declined due to habitat degradation. The peat-bog pine population from Weggliniec reserve is small and threatened with extinction because of the lack of its natural regeneration and the gradual decline of older trees. Currently, there are about 98 trees in the reserve, but over $50 \%$ of them is wea- 
kened or dying back. The size of population has decreased by over half within the last 42 years (Danielewicz and Zieliński 2000). The remaining Polish populations of peat-bog pine are also endangered and the species has been included in the Polish Plant Red Data Book (Staszkiewicz 2001).

Recently, three approaches for protective activities of peat-bog pine have been formulated by Danielewicz and Zieliński (2000): (1) supporting the population within the framework of reserve conservation by improving growth conditions for $P$. uliginosa trees and creating conditions for its natural regeneration; (2) protection of genetic resources of $P$. uliginosa by archiving the genotypes through conservation plantations; (3) creating secondary sites of $P$. uligino$s a$ in environments similar to those in which colonization of the species may have occurred.

In order to create new populations from seedlings we need information about genetic quality of seeds produced in endangered populations. Pines are known to be predominantly outcrossed, but in small, isolated populations a degree of selfing and inbreeding may increase, partly due to related matings. Abnormal levels of inbreeding may have implications for seed and seedling performance during plantation establishment, thus altering ex situ conservation programs. Additionally, some peat-bog populations (e.g. in Wegliniec) are located in the vicinity of closely related $P$. sylvestris and thus are theoretically exposed to constant inflow of its genes through pollen, leading to further species extinction (Ferdy and Austerlitz 2002). These concerns seem to be important as the observations of phenology revealed only slight differences in flowering periods of the two species.

In this paper we have investigated the genetic quality of seeds of $P$. uliginosa collected in the Wegliniec reserve for the purpose of ex-situ conservation program. The two subjects that we have investigated relate to: (1) the levels of allozyme variation and inbreeding in seeds; (2) the possibility of genetic erosion of $P$. uliginosa resulting from hybridization with $P$. sylvestris. Basing on phenological observations, firstly we have evaluated the possibility of cross-pollination between $P$. sylvestris and $P$. uliginosa, and then through applying species specific $c p$ DNA marker we analysed seedlings of $P$. uliginosa estimating the actual level of hybridization.

\section{MATERIAL AND METHODS}

\section{Study area}

The study site was the Weqgliniec reserve $\left(51^{\circ} 17^{\prime} \mathrm{N}\right.$, $15^{\circ} 14^{\prime}$ E), located in the area of Lower Silesian Pinewood, Poland. The population of $P$. uliginosa in Wegliniec is isolated from other populations of the taxon and surrounded by extensive forest stands of $P$. sylvestris. The area of the reserve is only 1.35 ha. The height of $P$. uliginosa trees ranges from $3.5 \mathrm{~m}$ to $16 \mathrm{~m}$, and most of them are about 9 $\mathrm{m}$ high. Over the last three decades there has been a large reduction in number of individuals, from 208 in 1956 to 98 in 1998, observable due to habitat degradation (Danielewicz and Zieliński 2000). It is worth noting that in spite of its isolation and small size the adult population of peat-bog pine from Węgliniec reserve has preserved a high level of genetic variation. The level of allozyme variation is comparable to the one in $P$. sylvestris considered to be the most variable coniferous trees in Europe (Lewandowski et al. 2002).

\section{Phenological observations}

The phenological observations were carried out in 1999 , 2000 and 2001, starting from early spring to the end of pollen release and the end of receptivity of female strobili on the last tested trees. At least ten individuals of each species ( $P$. uliginosa and $P$. sylvestris) were observed every year. The observations were conducted with the use of binoculars twice a week. According to Jonsson et al. (1976), during field observations we distinguished four distinct developmental stages of megastrobili and six of microstrobili. The duration of pollen release by microstrobili and pollen reception by megastrobili were calculated separately for $P$. uliginosa and $P$. sylvestris.

\section{Mating system and genetic diversity of offspring}

Mating system was investigated basing on 740 offspring (seed embryos) collected in autumn 2000 from 14 mother trees. The eleven of polymorphic allozyme loci used are the following: Adh1 (alcohol dehydrogenase), Fle (fluorescent esterase), Gdh (glutamate dehydrogenase), Got1 (glutamate oxalo-acetate transaminase), Lap2 (leucine aminopeptidase), Mdh1, Mdh3, Mdh4 (malate dehydrogenase), 6Pgd1, 6Pgd2 (6-phosphogluconate dehydrogenase), Pgm (phosphoglucomutase). The separation of allozymes on starch gels and the genetic interpretation of the results were performed according to the results obtained for closely related P. sylvestris species by Rudin and Ekberg (1978), Szmidt and Yazdani (1984) and Goncharenko et al. (1994). Parameters describing genetic variation of mother trees and seed embryos, including mean $(\mathrm{Na})$ and effective $(\mathrm{Ne})$ numbers of alleles per locus, expected heterozygosity $(\mathrm{He})$ and fixation index $(F)$ were obtained using Pop Gen computer program (Yeh et al. 1997). The population single-locus $\left(\mathrm{t}_{\mathrm{s}}\right)$ and multilocus $\left(\mathrm{t}_{\mathrm{m}}\right)$ estimates of outcrossing rate, as well as several other parameters, including correlation of paternity $\left(\mathrm{r}_{\mathrm{p}}\right)$ and correlation of outcrossing $\left(r_{t}\right)$, were calculated on the basis of the mixed-mating model and maximum-likelihood procedures using the MLTR for Windows computer program (Ritland 2002). The multilocus outcrossing rates for individual 14 mother trees were also estimated.

\section{cpDNA analyses}

In order to investigate hybridization events we used a cpDNA marker which is species specific for $P$. sylvestris and P. mugo (Wachowiak et al. 2000). PCR-RFLP analyses of trnL-trnF cpDNA region of $P$. uliginosa individuals from the locus classicus of the species from the "Wielkie Torfowisko Batorowskie" peat bog in Poland revealed one DraI restriction site in that region in $P$. uliginosa, similarly as in the case of $P$. mugo (Wachowiak et al. 2000). However, DraI restriction site does not occur in trnL-trnF cpDNA region in $P$. sylvestris. Consequently, restriction analysis of respective PCR products differentiates $P$. sylvestris samples (no digestion) versus $P$. mugo and $P$. uliginosa. Since in Pinaceae the chloroplast DNA is transmitted paternally (Neale et al. 1986) this marker is useful to indicate introgression between $P$. uliginosa and $P$. sylvestris in the sympatric populations of the species. The cpDNA haplotypes were determined for 44 parental trees of $P$. uliginosa and their F1 progeny consisting of 533 seedlings sampled 


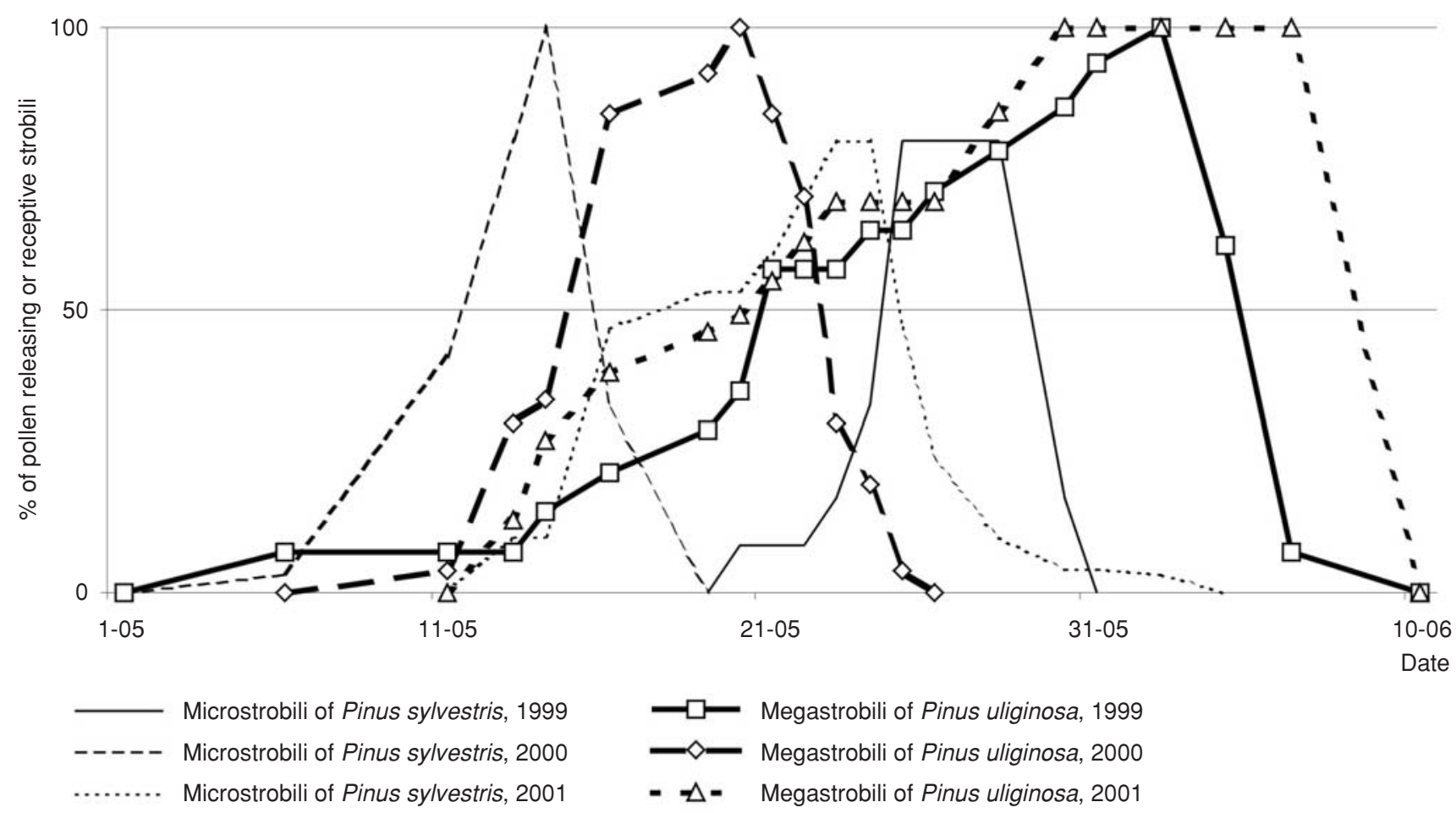

Fig. 1. Development of megastrobili of Pinus uliginosa and microstrobili of P. sylvestris at Węgliniec.

from 1999 to 2001 (235 seedlings from 33 trees in 1999; 107 and 191 seedlings each from eight trees in 2000 and 2001, respectively).

Two weeks-old seedlings and the needles from the parental individuals (ca. $100 \mathrm{mg}$ of fresh material) underwent DNA isolation using method described by Dumolin et al. (1995). PCR amplification was carried out in a total volume of $25 \mu$ l containing about $20 \mathrm{ng}$ of template DNA, 2.5 $\mathrm{mM} \mathrm{MgCl} 2,100 \mu \mathrm{M}$ of each of dNTP, $0.2 \mu \mathrm{M}$ each of primer and $0.25 \mathrm{U}$ Taq polymerase with the respective $1 \times \mathrm{PCR}$ buffer (Taq polymerase and 10×PCR buffer were provided by Fermentas, Lithuania), following the cycle profile and primers described by Taberlet et al. (1991). The PCR products $(10 \mu \mathrm{l})$ were subjected to the restriction analyses at $37^{\circ} \mathrm{C}$ over night. After digestion, the samples were separated in $2 \%$ agarose gel (Sambrook, et al. 1989), stained with ethidium bromide and analyzed by UV light.

\section{RESULTS}

\section{Phenological observations}

The periods of successive phenophases of $P$. uliginosa and $P$. sylvestris micro- and megastrobili were variable each year and were largely influenced by weather conditions. The time differences of phenophases between an extremely early, dry and warm spring in the year 2000, and late and cold springs in the years 1999 and 2001, were 10 days for $P$. uliginosa and 18 days for $P$. sylvestris. In both species the megastrobili were developing earlier than microstrobili. The differences in periods of maturation of micro- and megastrobili were the least in 2000, reaching on average only about 0.5 day for $P$. uliginosa and 1.4 day for P. sylvestris. However, in 1999 and 2001 megastrobili were receptive up to 2 weeks before the pollen has been released from the same individuals. Every year $P$. sylvestris released pollen at the time of receptivity of pollen by $P$. uliginosa megastrobili (Fig. 1).

\section{Level of allozyme variation}

A summary of genetic variability measures at eleven allozyme loci for the sampled mother trees and embryos are given in Table 1. Generally, a high and relatively similar level of allozyme variation was observed. The average (Na) and effective $(\mathrm{Ne})$ numbers of alleles per locus were 2.09 and 1.66 for mother trees, while 2.45 and 1.67 for seed embryos, respectively. Mother trees exhibited a 5\% excess of heterozygotes $(\mathrm{F}=-0.047)$, according to the Hardy-Weinberg equilibrium. Contrary, in embryo we observed a $17 \%$ excess of homozygotes (Table 1).

\section{Mating system}

The population-wide multilocus outcrossing rate was estimated to be $0.706( \pm 0.091)$. However, the minimum variance mean of single-locus estimates was distinctly lower $\left(t_{s}=0.611 \pm 0.112\right)$. The difference between multi- and single-

TABLE 1. Genetic variability at 11 allozyme loci in the maternal trees and embryos (standard deviations in parentheses).

\begin{tabular}{lcccc}
\hline & Sample size & $\mathrm{Na}$ & $\mathrm{Ne}$ & $\mathrm{He}$ \\
\hline Maternal trees & 14 & $2.09(0.30)$ & $1.66(0.30)$ & $0.376(0.129)$ \\
Embryos & 740 & $2.45(0.69)$ & $1.67(0.29)$ & $0.376(0.133)$ \\
\hline
\end{tabular}


TABLE 2. The multilocus outcrossing rates and correlation of paternity estimated for the offspring of individual mother trees of Pinus uliginosa and the entire sampled population (standard deviation in parentheses).

\begin{tabular}{|c|c|c|c|}
\hline Mother tree & Sample size & Outcrossing rate & Correlation of paternity $\left(\mathrm{r}_{\mathrm{p}}\right)$ \\
\hline 01 & 57 & $1.017(0.091)$ & $0.696(0.099)$ \\
\hline 02 & 57 & $0.987(0.050)$ & $0.048(0.045)$ \\
\hline 03 & 56 & $0.072(0.028)^{\mathrm{a}}$ & $-0.200(0.000)$ \\
\hline 04 & 76 & $0.796(0.046)^{\mathrm{a}}$ & $0.094(0.066)$ \\
\hline 05 & 57 & $0.595(0.068)^{\mathrm{a}}$ & $0.143(0.058)$ \\
\hline 06 & 59 & $0.994(0.070)$ & $0.027(0.025)$ \\
\hline 08 & 46 & $0.051(0.034)^{\mathrm{a}}$ & $0.999(0.206)$ \\
\hline 09 & 42 & $0.939(0.107)$ & $0.050(0.060)$ \\
\hline 10 & 57 & $0.684(0.076)^{\mathrm{a}}$ & $0.285(0.121)$ \\
\hline 11 & 47 & $0.735(0.064)^{\mathrm{a}}$ & $0.149(0.077)$ \\
\hline 12 & 52 & $0.593(0.059)^{\mathrm{a}}$ & $0.077(0.050)$ \\
\hline 13 & 19 & $0.967(0.135)$ & $0.157(0.114)$ \\
\hline 14 & 60 & $0.648(0.065)^{\mathrm{a}}$ & $0.078(0.047)$ \\
\hline Pooled & 740 & $0.706(0.091)^{\mathrm{a}}$ & $0.188(0.096)$ \\
\hline
\end{tabular}

a - parameter significantly different from $t=1$ at $P<0.001$ level

locus parameters appeared to be statistically significant $\left(\mathrm{t}_{\mathrm{m}}-\right.$ $\mathrm{t}_{\mathrm{s}}=0.095 \pm 0.030$ ), indicating that some proportion of inbreeding additional to selfing (i.e., biparental inbreeding) may be present among offspring. Nevertheless, the high correlation of outcrossing rates among loci $\left(r_{t}=0.947 \pm 0.109\right)$, suggests that biparental inbreeding is rather low as compared to uniparental inbreeding (selfing). The correlation of outcrossed paternity within progeny arrays (or the probability that a randomly chosen pair of progeny from the same array are full sibs, Ritland 2002) was low ( $\left.r_{p}=0.188 \pm 0.096\right)$, indicating that on average, the number of outcrossing males mating with a given mother tree was relatively high.

The correlation of outcrossing rate within progeny arrays (normalized variation of outcrossing rate among progeny arrays, Ritland 2002) was high (0.412 \pm 0.157$)$, suggesting considerable variation of outcrossing rate among individual mother trees. This has been confirmed by individual-tree estimates ranging widely from 0.051 (tree \#08) to 1.017 (tree \#01) (Table 2). The biologically unrealistic value for tree \#01 (although not significantly different from 1), may result from a negative assortative mating. The correlation of paternity within the progeny array of that tree was very high $\left(r_{p}=0.696 \pm 0.099\right)$ indicating that the outcrossing pollen came from very few individuals. Eight out of 14 trees exhibited outcrossing rates significantly lower than unity (Table 1). This means in general, that offspring of particular mother trees may be highly selfed $(s=1-t)$, potentially altering levels of inbreeding depression.

\section{cpDNA analyses}

All the parental trees of $P$. uliginosa displayed the haplotype of trnL-trnF cpDNA region typical to the species. In the group of $533 P$. uliginosa seedlings there were only six individuals identified with cpDNA haplotype specific to $P$. sylvestris. Three of them are dated to 1999 and the other three to 2001 .

\section{DISCUSSION}

The three-year records of phenological observations prove that growth periods for $P$. uliginosa megastrobili and $P$. sylvestris microstrobili overlap, enabling cross-pollination. The possibility of $P$. uliginosa being pollinated by $P$. sylvestris creates potential danger of genetic erosion of the $P$. uliginosa gene pool. This probability increases because the investigated $P$. uliginasa population in Wegliniec is small and surrounded by extensive forest stands of $P$. sylvestris. However, our studies with the aid of $c p$ DNA marker indicated that introgression from $P$. sylvestris to $P$. uliginosa is rare. The presence of only six among 533 seedlings derived from $P$. uliginosa mother trees contained $P$. sylvestris plastid DNA. This indicates that such hybridization process seems not to affect the cohesion of natural gene pool of $P$. uliginosa. Also latest biometric analyses indicated the lack of effective hybridization between $P$. uliginosa and $P$. sylvestris at Węgliniec (Boratyńska et al. 2003). Nevertheless, our results point out the possibility that hybrids of both species may appear among seedlings derived from the $P$. uliginosa seeds obtained from sympatric population of the species. According to our observations, such introgression is more likely when megastrobili of $P$. uliginosa become receptive much earlier before its pollen shedding (as in 1999 and 2001). However, the time differences between mega- and microstrobili phenophases are variable from year to year, mostly due to weather conditions. In order to exclude hybrids, seedlings of $P$. uliginosa intended for reintroduction purposes may be preceded by their cpDNA haplotype analyses. The cpDNA marker described above constitutes an efficient tool for this type of research. Thus, the obtained results suggest the existence of natural barriers restricting the hybridization process with $P$. uliginosa as a pollen acceptor.

The progeny (embryos) preserved high levels of allozyme variations, which is consistent with the results reported earlier for the adult population from Weggliniec (Lewandowski et al. 2002). The mean of F over loci for the maternal trees $(\mathrm{F}=-0.047)$ indicated an excess of heterozygotes. In contrast, the mean of $F$ over progeny loci was positive (Table 1), indicating inbreeding in the seed crop. The reduction in homozygosity between the two life stages (seed embryos and adults) could be due to selection against inbreds. This phenomenon has often been reported in conifers, which usually show a noticeable selfing and inbree- 
ding depression attributed to the action of recessive lethals and deleterious alleles (Shaw and Allard 1982; Lewandowski et al. 1991; Morgante et al. 1991; Williams and Savolainen 1996).

Conifers are known to be predominantly outcrossing (Stern and Roche 1974), however a variable and sometimes significant amount of selfing has been observed in natural populations of different species. High self-fertilization levels, similar to those of Pinus uliginosa, have also been reported for Pinus leucodermis (Morgante et al. 1991), Larix laricina (Knowles et al. 1987), Thuja occidentalis (Perry and Knowles 1990) and Thuja orientalis (Xie et al. 1991). Selfing higher than average was often observed at marginal populations in upper mountains or at the northern limit of species distribution (Karkkainen et al. 1996; Hedrick et al. 1999; Lewandowski and Burczyk 2000). The possibility of selfing allows population to survive during unfavorable conditions when the amount of outcross pollen is limited.

Relatively low levels of outcrossing, and potential biparental inbreeding draw attention to the strategy of seed sampling for gene conservation purposes. We demonstrated that individual mother trees may exhibit very low outcrossing rates (high self-fertilization). Sampling offspring from such trees not only decreases the genetic diversity of next generations, but increases the probability of inbreeding depression expressed as high mortality, or low growth performance. The considerable variation of outcrossing rates among mother trees is probably a result of genetic differences among individuals in their self-fertility.

The need to maintain diversity and reduce the effects of inbreeding in seeds from the Weqgliniec reserve is evident. Therefore collecting seed for gene conservation should take into consideration two steps: Firstly, mother trees with higher outcrossing rates should be selected; Secondly, among the trees with high outcrossing rates the trees with low correlation of paternity $\left(r_{p}\right)$ (i.e., the mother trees which mated with a large number of males) should be preferred. Such procedure would enable to maximize genetic diversity of the offspring, avoiding high inbreeding levels.

\section{LITERATURE CITED}

BORATYŃSKA K., BORATYŃSKI A., LEWANDOWSKI A. 2003. Morphology of Pinus uliginosa (Pinaceae) needles from populations exposed to and isolated from the direct influence of Pinus sylvestris. Botanical Journal of the Linnean Society 142: 83-91.

BORATYŃSKI A. 1994. Protected and rare trees and shrubs from the Polish part of Sudety Mts. and its foothills. 7. Pinus mugo Turra and $P$. uliginosa Neumann. Arboretum Kórnickie 39: 63-85.

CHRISTENSEN K.I. 1987. Taxonomic revision of the Pinus mugo complex and $P$. x rhaetica $(P$. mugo $\times P$. sylvestris (Pinaceae). Nordic Journal of Botany 7: 383-408.

DANIELEWICZ W., ZIELIŃSKI J. 2000. Ochrona sosny błotnej Pinus uliginosa Neuman na terenie Borów Dolnośląskich. (Protection of the longleaf Pinus uliginosa Neuman in the Low Silesian Pinewood area). Przegląd Przyrodniczy 11: 113124. (in Polish with English summary)

DUMOLIN S., DEMESURE B., PETIT R.J. 1995. Inheritance of chloroplast and mitochondrial genomes in pedunculate oak investigated with an efficient PCR method. Theoretical and Applied Genetics 91: 1253-1256.
FERDY J.-B., AUSTERLITZ F. 2002. Extinction and introgression in a community of partially cross-fertile plant species. American Naturalist 160: 74-86.

GONCHARENKO G.G., SILIN A.E., PADUTOV V.E. 1994. Allozyme variation in natural populations of Eurasian pines. III Population structure, diversity, differentiation, and gene flow in Pinus sylvestris L. in central and isolated populations of eastern Europe and Siberia. Silvae Genetica 43: 119-132.

HEDRICK P.W., HEDRICK P.W., SAVOLAINEN O., KARKKAINEN K. 1999. Factors influencing the extent of inbreeding depression: an example from Scots pine. Heredity 82: 441-450.

JONSSON A., EKBERG I., ERIKSSON G. 1976. Flowering in a seed orchard of Pinus sylvestris L. Studia Forestalia Suecica 135: $1-38$.

KARKKAINEN K., KOSKI V., SAVOLAINEN O. 1996. Geographical variation in the inbreeding depression of Scots pine. Evolution 50: 111-119.

KNOWLES P., FURNIER G.R., ALEKSIUK M.A., PERRY D.J. 1987. Significant levels of self-fertilization in natural populations of tamarack. Canadian Journal of Botany 65: 1087-1091.

KRZAKOWA M., NAGANOWSKA B., BOBOWICZ M.A. 1984. Investigations on taxonomic status of Pinus uliginosa Neumann. Bulletin de la Societe des Amis Sciences et des Letters de Poznań, Ser. D 24, 87-96.

LAURANSON-BROYER J., KRZAKOWA M., LEBRETON P. 1997. Reconnaissance chimiosystematique et biometrique du pin de tourbiere Pinus uliginsa (Neumann). Comptes Rendus de 1' Academie des Sciences, Serie III, Sciences de la Vie 320: 557-565.

LEWANDOWSKI A., BURCZYK J., MEJNARTOWICZ L. 1991. Genetic structure and the mating system in an old stand of Polish larch. Silvae Genetica 40: 75-79.

LEWANDOWSKI A., BORATYŃSKI A., MEJNARTOWICZ L. 2000. Allozyme investigations on the genetic differentiation between closely related pines - Pinus sylvestris, $P$. mugo, $P$. uncinata and P.uliginosa (Pinaceae). Plant Systematics and Evolution 221: 15-24.

LEWANDOWSKI A., BURCZYK J. 2000. Mating system and genetic diversity in natural populations of European larch ( $\mathrm{La}$ rix decidua) and Stone pine (Pinus cembra) located at higher elevations. Silvae Genetica 49: 158-161.

LEWANDOWSKI A., SAMOĆKO J., BORATYŃSKA K., BORATYŃSKI A. 2002. Genetic differences between two Polish populations of Pinus uliginosa compared to $P$. sylvestris and P. mugo. Dendrobiology 48: 51-57.

MORGANTE M., VENDRAMIN G.G., OLIVIERI A.M. 1991. Mating system analysis in Pinus leucodermis Ant.: detection of self-fertilization in natural populations. Heredity 67: 197-203.

NEALE D.B., WHEELER N.C., ALLARD R.W., Neale D.B. 1986. Paternal inheritance of chloroplast DNA in Douglas-fir. Canadian Journal of Forest Research 16: 1152-1154.

PERRY D.J., KNOWLES P. 1990. Evidence of high self-fertilization in natural populations of eastern white cedar (Thuja occidentalis). Canadian Journal of Botany 68: 663-668.

PRUS-GŁOWACKI W., BUJAS E., RATYŃSKA H. 1998. Taxonomic position of Pinus uliginosa Neumann as related to the other taxa of Pinus mugo complex. Acta Societatis Botanicorum Poloniae 67: 269-274.

RITLAND K. 2002. Extensions of models for the estimation of mating systems using $n$ independent loci. Heredity 88: 221-228.

RUDIN D., EKBERG I. 1978. Linkage studies in Pinus sylvestris using macrogametophyte allozymes. Silvae Genetica 27: 1-11.

SAMBROOK J., FRITSCH E.F., MANIATIS T. 1989. Molecular Cloning a Laboratory Manual, 2nd edn. Cold Spring Harbor Laboratory Press, New York.

SHAW D.V., ALLARD R.V. 1982. Isoenzyme heterozygosity in adult and open-pollinated embryo samples of Douglas-fir. Silvae Fennica 16: 115-121. 
STERN K., ROCHE F. 1974. Genetics of Forest Ecosystems. Springer-Verlag, Berlin.

SZMIDT A.E., YAZDANI R. 1984. Electrophoretic studies of genetic polymorphism of shikimate and 6-phosphogluconate dehydrogenases in Scots pine (Pinus sylvestris). Arboretum Kórnickie 29: 63-72.

STASZKIEWICZ J. 1985. Kilka uwag o sośnie błotnej Pinus uliginosa. (Some remarks on the Peat-bog pine Pinus uliginosa). Chrońmy Przyrodę Ojczystą 41 (5): 56-61. (in Polish with English summary)

STASZKIEWICZ J., TYSZKIEWICZ M. 1972. Variability of the natural hybrids of Pinus sylvestris L. $\times$ Pinus mugo Turra $(=P$. rotundata Link) in South-western Poland and in some selected localities of Bohemia and Moravia. Fragmenta Floristica et Geobotanica 18: 173-191. (in Polish)

STASZKIEWICZ J. 2001. Pinus $\times$ Rhaetica Brügger. In: Polish Red Data Book of Plants, (eds) R. Kaźmierczakowa and K. Zarzycki, pp. 65-66. Polish Academy of Sciences, W. Szafer Institute of Botany, Institute of Nature Conservation, Kraków.
TABERLET P., GIELLY L., PAUTON G., BOUVET J. 1991. Universal primers for amplification of three non-coding regions of chloroplast DNA. Plant Molecular Biology 17: 1105$-1109$.

WACHOWIAK W., LEŚNIEWICZ K., ODRZYKOSKI I., AUGUSTYNIAK H., PRUS-GŁOWACKI W. 2000. Species specific $c p$ DNA markers useful for studies on the hybridization between Pinus тияo $\times$ P. sylvestris. Acta Societatis Botanicorum Poloniae 69: 273-276.

WILLIAMS G.G., SAVOLAINEN O. 1996. Inbreeding depression in conifers: implications for breeding strategy. Forest Science 42: 102-107.

XIE C.Y., DANCIK B.P., YEH F.C. 1991. The mating system in natural populations of Thuja orientalis. Canadian Journal of Forest Research 21: 333-339.

YEH F.C., YANG R.-C., BOYLE T. 1997. Pop-Gene, Version 1.20. Microsoft-based Freeware for Population Genetics Analysis. University of Alberta. 